\title{
Geoheritage and Geodiversity Education in Romania: Formal and Non-Formal Analysis Based on Questionnaires
}

\author{
Laura Comănescu and Alexandru Nedelea * \\ Geomorphology-Pedology-Geomatics Department, Faculty of Geography, University of Bucharest, \\ 10043 Bucharest, Romania; laura.comanescu@geo.unibuc.ro \\ * Correspondence: alexandru.nedelea@geo.unibuc.ro
}

Received: 9 October 2020; Accepted: 2 November 2020; Published: 4 November 2020

check for updates

\begin{abstract}
This paper aims to present how education for geoheritage and geodiversity should take place both in the school curriculum and in extracurricular activities at all levels of Romanian education (middle school, high school and university). The research method consisted in applying two questionnaires (10 questions, most with answers to choose from) both to pre-university teachers (especially those in geography) and students/graduates (especially from geography faculties in the country). The obtained results demonstrate the existence of two different visions: for middle and high school education, education on geoheritage and geodiversity takes place sometimes formally (based on curriculum hours according to the school's decision) but predominantly informally (based on practical field applications), with most schools educationally limited in terms of environment/sustainable development; in contrast, university education on these subjects has a formal character (based on dedicated courses or field practice modules). The results, although encouraging for the moment, show that there is a need to intensify awareness and education on geoheritage and geodiversity at all levels, especially in higher education, by introducing specific courses/content at all universities in the country.
\end{abstract}

Keywords: geoheritage; geodiversity; geoeducation; Romania

\section{Introduction}

In most scientific papers, geological heritage is considered to be composed of all geosites in an area, while the geomorphological heritage is the set of geomorphosites [1]. Geoheritage is also related to cultural heritage, in which links are established over time between human society and relief [1-5]. Its educational component is highlighted by the relationship between geoheritage and the biological or cultural-historical elements of the respective space [6]. In the scientific literature on the inventory and evaluation of geoheritage, there are numerous and varied methods, differing depending on their purpose [7-20]. Geodiversity represents the totality of geological, geomorphological, pedological and hydrogeological elements in a certain area [21,22] or the connection between people, landscape and culture [23,24]. A more nuanced definition is formulated by [25], who defines geodiversity as "the critical and specific assessment of the geomorphological characteristics of a territory, comparing them in an intrinsic and extrinsic way, taking into account the scale of investigation, purpose and scientific level of research" [26]. The purpose and scientific level of the research takes into account the educational component of geodiversity. The theoretical framework and evaluation methodologies have evolved over time [27-29]. Thus, the assessment of geodiversity must take into account the following types of values: intrinsic, cultural, aesthetic, economic, education and research, and support for the functioning of the geosystem $[27,30]$. The value for education and research has special importance, and it must be the basis of a specific form of seducation, namely geoeducation. 
According to [31], geodiversity can be used by the scientific community (geoscientists, social scientists) and for educational purposes (formal or informal) to provide students and society with knowledge about changes that occur over time in Earth's geospheres.

In the international literature, the concept of geoeducation [32-35] refers to education about the Earth as a whole to provide an understanding of how the natural and human components of the geographic environment function and interact locally, regionally and globally [36]. Geoeducation involves learning both in and out of school (Figure 1). In school, geoeducation takes place in several subjects of the traditional national curriculum, and out of school, it takes place through guided experiences (field trips, projects, visits) both in the natural and in the anthropized environment.

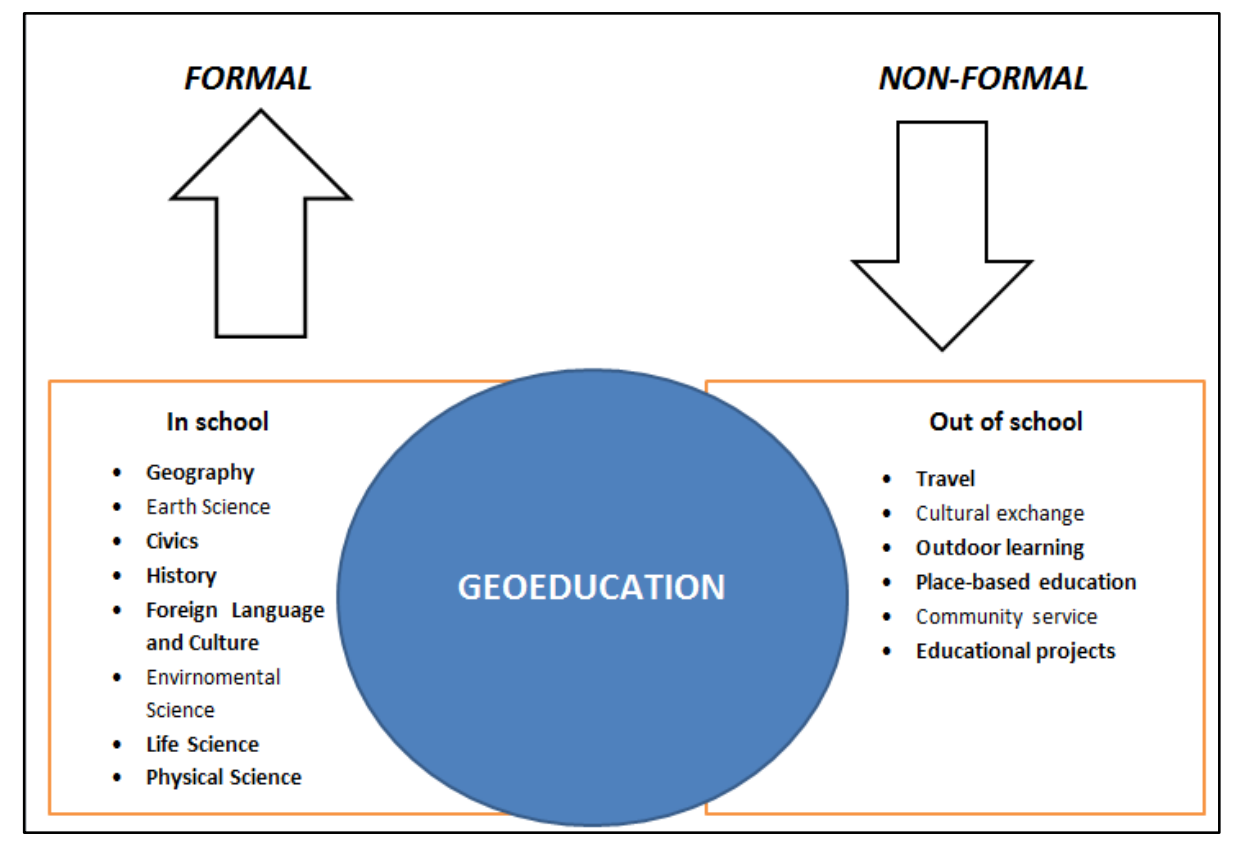

Figure 1. Geoeducation - formal and non-formal components (according to [36] with modifications and additions) (with bold elements specific to Romania).

In Romania, the concept of geoeducation was introduced simultaneously with those related to geomorphosites, geotourism, geodiversity and geoheritage. The vision related to geoeducation is synonymous with environmental education, especially for earth-related components, and aims to raise public awareness of the important position that geoheritage and geodiversity play in knowing the values of an area and its sustainable development, such as and for establishing the most appropriate ways for to exploit tourism (geotourism) and for protection and conservation (geoconservation) [16].

There are a small number of works dealing with the concrete ways in which geoeducation is carried out in different countries of the world, and these are completely missing in the Romanian scientific literature.

The purpose of this paper is to observe the way in which an important side of geoeducation (that of geoheritage and geodiversity) is perceived and understood in the Romanian school.

\section{Methodology}

The questionnaire method (using two types of questionnaires applied to pre-university teachers and students) was used to achieve the proposed goal (Tables 1 and 2). The data obtained were correlated with other information from the literature or with discussions with teachers in higher education, both in the field of geography and education sciences.

The questionnaire given to pre-university teachers (Table 1) included three sections: Section 1 , the interviewee's form, in which the respondent's identification data are requested (the educational 
institution where they work, the discipline taught, the study cycle they teach and seniority in education); Section 2, general notions about heritage and geodiversity (knowledge of concepts and related terms, biodiversity and evaluation of their importance); Section 3, teaching experience (use of specialized terminology in curricular and extracurricular context, activities/projects proposed/carried out with students, the need to introduce these notions in the curriculum and designing a curriculum at the school's decision that contains this issue).

The questionnaire given to students/graduates from geography faculties (Table 2) was also structured in three parts: part 1, interviewee's form (higher education institution and the faculty where is a student/graduate, study cycle, specialization and year); part 2, general notions about geoheritage and geodiversity (knowledge of concepts, type of didactic activity with which they were taught, the importance of natural heritage and measures for its conservation); part 3, didactic component (need to include in the curriculum some disciplines/contents related to these notions, carrying out non-formal activities and assessing the importance of the notions of natural heritage and geodiversity).

The questionnaires were applied between June and September 2020, on samples as representative as possible in structure (Tables 3 and 4). Thus, 120 responses were collected for pre-university teachers and 71 for students.

In the case of the sample of pre-university teachers, teachers from 37 counties and the city of Bucharest responded ( $88.37 \%$ of the country's territorial administrative units), who teach mainly geography and geography in association with another discipline $(94.18 \%)$ or auxiliary geography such as Tourism and Tourist Orientation (1.66\%). Notably, some respondents were located in the southern part of the country, around the university center of Bucharest. The interviewees taught at all cycles of education (a slight predominance of those in high school) and were distributed in all categories of seniority at the school.

It can be noticed in the case of the sample of students that it is quite heterogeneous, covering a wide range of study programs (there were a number of equivalences of the name of programs between faculties) in Geography and Environmental Science (4 undergraduate specializations and 5 master's degree) and the whole range of study cycles. Students were enrolled in 7 universities (six public and one private), with the University of Bucharest showing a clear dominance as an institution of origin $(85.9 \%)$.

In the case of both samples, identification data related to age, sex, place of origin, etc. were not considered necessary. 
Table 1. The questionnaire given to pre-university teachers.

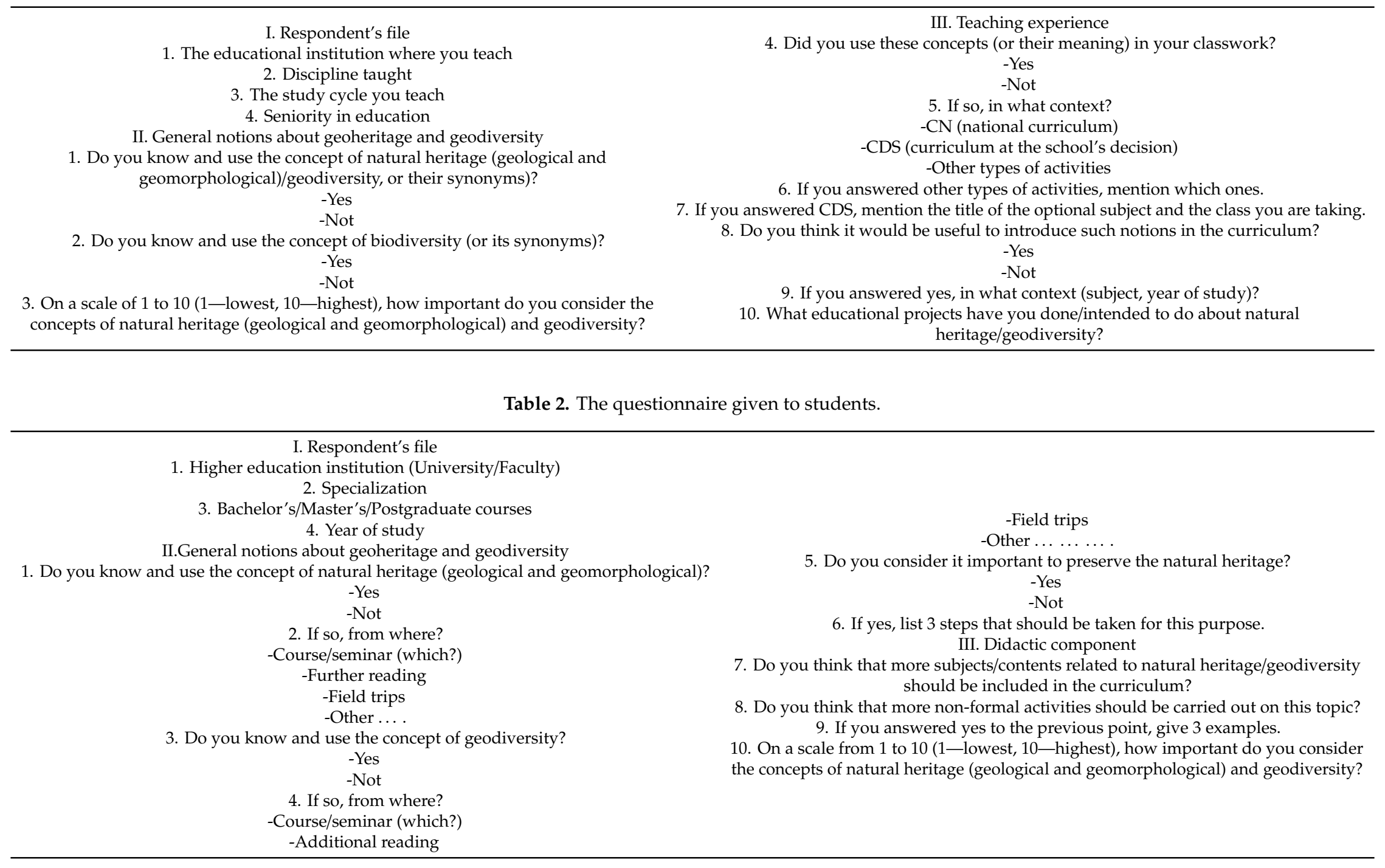


Table 3. Sample structure for teachers.

\begin{tabular}{cccccc}
\hline Discipline Taught (\%) & \multicolumn{2}{c}{ Study Cycle They Teach (\%) } & \multicolumn{2}{c}{ Seniority in the Department (\%) } \\
\hline Geography & 88.36 & Lower secondary education & 41.66 & Less 5 years & 23.20 \\
Geography-History & 3.33 & Upper secondary education & 30.00 & $5-10$ years & 17.30 \\
Geography-Biology & 0.83 & Mixed & 28.34 & $10-15$ years & 8.30 \\
Geography-Chemistry & 0.83 & & & 15-20 years & 16.90 \\
Geography-Foreign Language & 0.83 & & More 25 years & 22.50 \\
Mathematics & 0.83 & & & \\
Tourism & 0.83 & & & \\
Tourist Orientation & 0.83 & & & \\
Logic-Philosophy & 0.83 & & & \\
Technical disciplines & 2.50 & &
\end{tabular}

Table 4. Sample structure for students.

\begin{tabular}{|c|c|c|c|c|c|}
\hline \multicolumn{2}{|c|}{ Higher Education Unit from Which They Come (\%) } & \multicolumn{2}{|c|}{$\begin{array}{c}\text { The Study Cycles } \\
(\%)\end{array}$} & \multicolumn{2}{|l|}{ Specialization $(\%)$} \\
\hline University of Bucharest & 85.9 & Bachelor & 43.6 & Geography & 52.21 \\
\hline Ovidius University Constanța & 7.1 & Master & 32.4 & Geography of Tourism & 18.30 \\
\hline University of Craiova & 1.4 & Post-graduate study & 24.00 & Geographic Information Systems & 5.63 \\
\hline Hyperion University of Bucharest & 1.4 & & & Cartography & 2.80 \\
\hline Valahia University of Târgoviște & 1.4 & & & Geomorphology and Cartography with Elements of Cadastre & 5.63 \\
\hline Babeș-Bolyai University of Cluj Napoca & 1.4 & & & Integrated Environmental Assessment & 5.63 \\
\hline \multirow[t]{3}{*}{ Stefan cel Mare University of Suceava } & 1.4 & & & Management of Tourist Resources and Activities & 4.20 \\
\hline & & & & Hydrology-Meteorology & 1.40 \\
\hline & & & & Disaster Management & 1.40 \\
\hline
\end{tabular}




\section{Results and Discussion}

The results obtained from the data processing contained in the two questionnaires shall be presented comparatively; there are many similar items, and it shall follow from student to teacher in describing how their use of the concepts of geoheritage and geodiversity evolved.

Regarding the knowledge of the notions of geoheritage and geodiversity, there is a very high percentage of respondents from both categories (over $97.00 \%$, with a slightly higher percentage of students) (Figure 2) who understand and use this terminology, which proves that in recent years, significant progress has been made in introducing these concepts in Romania. Progress has been made especially in universities by introducing dedicated courses or content (e.g., Geomorphosites at the University of Bucharest, content at the University of Oradea, Craiova, Cluj Napoca, etc.), by the presence of specialized sites and also by the increasing number of scientific and popular works in the field, including doctoral, master's or bachelor's theses with such subjects.

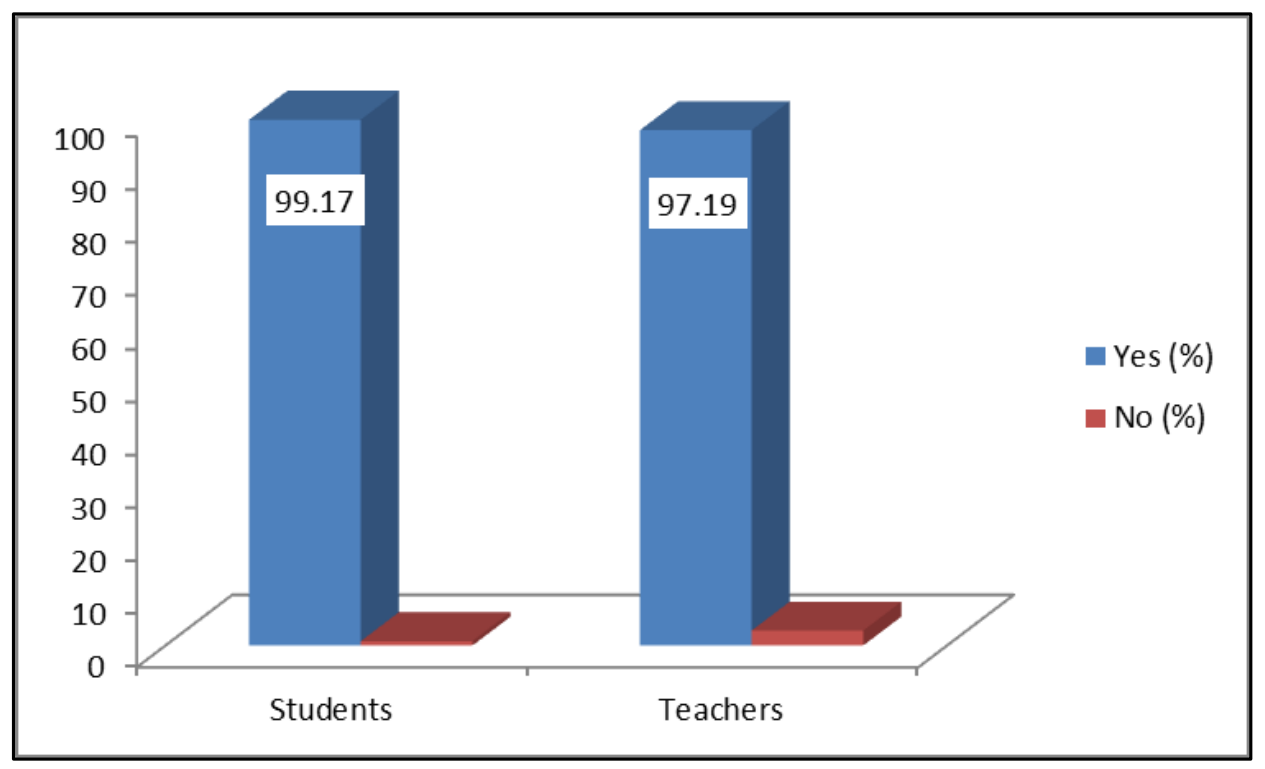

Figure 2. The percentages of interviewees who know/use the notions of geoheritage and geodiversity.

The term biodiversity is used by all interviewed teachers. Unlike geodiversity, which has been in the Romanian literature for about 10 years [16], the concept of biodiversity has been operating in Romania for over 20 years, with numerous works/projects/sites with this content.

For students, the concept of natural heritage is known from courses and seminars $(54.65 \%)$, additional readings $(27.90 \%)$ and field trips $(17.45 \%)$. The concept of geodiversity was addressed in courses and seminars $(52.29 \%)$, additional readings (25.68\%) and field trips $(22.03 \%)$. Among the disciplines teaching about these concepts are the following: Geology, General Physical Geography, Physical Geography of Romania, Geomorphology, General Tourist Potential, Environmental Geography. Of course, there may be some confusion: for example, in the subject General Tourist Potential, the terms of tourist/cultural heritage have been introduced, and in Geography of the Environment, that of biodiversity.

In order to highlight the connection between the didactic context (course and seminar, additional reading and practical activities) in which the acquisition of the two notions took place, we see that such a connection between geoheritage and geodiversity among students is direct and strong, with a correlation coefficient of 0.98 (Figure 3). This coefficient, very close to 1 , indicates that the two notions were introduced in parallel in the curriculum (either in the course/seminar or in practical activities). 


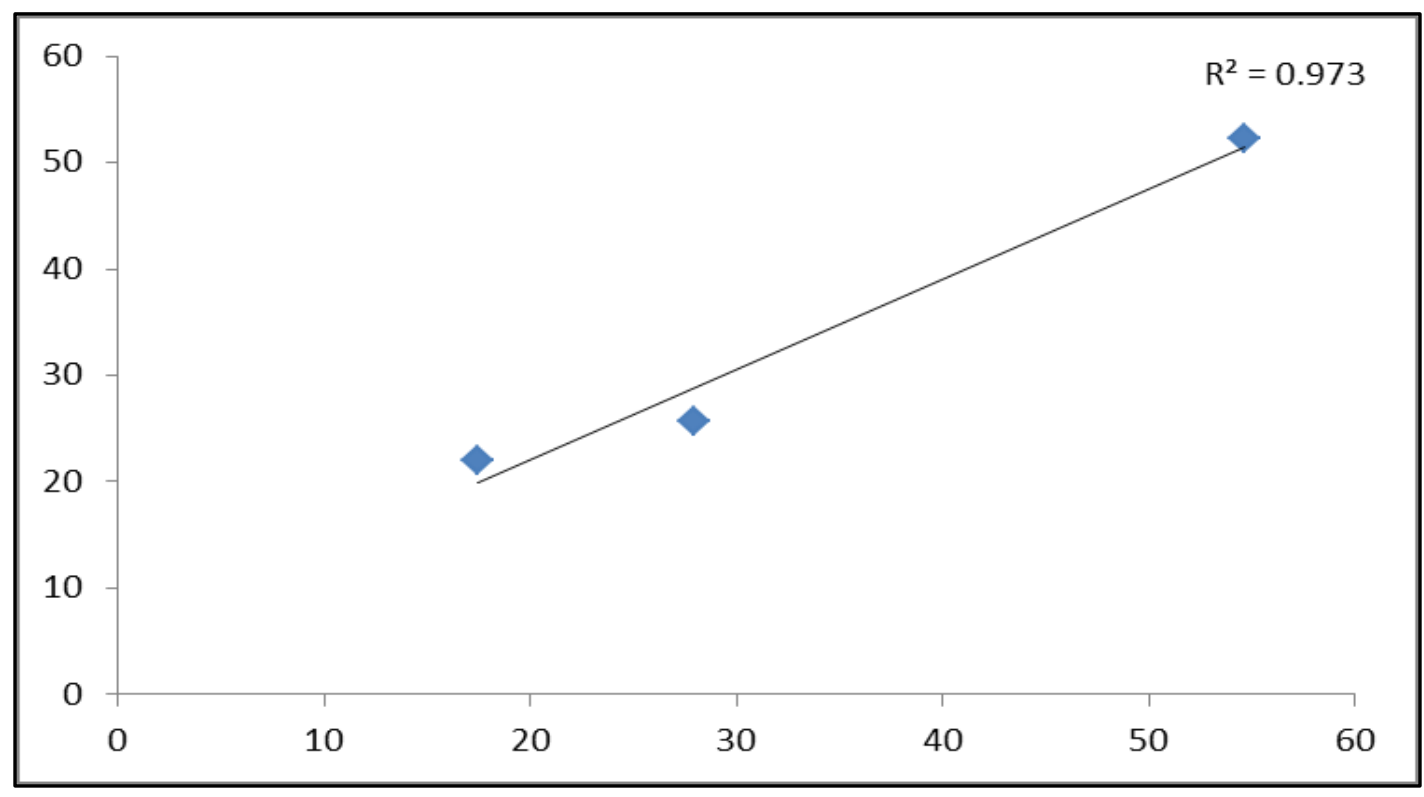

Figure 3. The correlation between the didactic context in which they introduced the concepts of geoheritage and geodiversity.

Students considered that these concepts should be deepened in the university curriculum $(94.36 \%)$, $4.22 \%$ answered that it depends on their approach and $1.42 \%$ considered that it is not necessary (the question was not understood because of the observation that children should not be overloaded). A series of additional remarks can also be made: the theoretical activities must be integrated with the practical ones (practical activities in the field) or non-formal ones (volunteer activities, students' involvement in projects). Thus, $92.95 \%$ considered non-formal activities on this topic absolutely necessary, while $7.05 \%$ did not consider them important or did not answer the question.

The non-formal activities indicated by the respondents are as follows: making advertising materials in order to raise awareness of the importance of natural heritage; establishing indicators along some geotourism routes; excursions/thematic camps/hiking/practical applications; creation of panels showing the importance of biodiversity/geodiversity and their display in schools; activities in kindergartens; thematic activities carried out by museums, botanical gardens, natural protected areas; thematic exchanges of experience with other states; involvement in the activities of students of the Ministry of Environment and NGOs; presenting short films/video material on the issue of natural heritage on public television; greening campaigns; workshops and summer schools; competitions on this topic held in schools; arranging geographical lands in the courtyard of the schools/research stations of the Universities; thematic photographic exhibitions.

At a rate of $94.36 \%$, teachers use these concepts in formal or non-formal activity. The exceptions are either teachers of another specialty (Mathematics) or teachers who have more than 20 years of experience in the school or teach in rural areas, so less contact with new scientific ideas. In order to highlight the context in which these notions were used by the teachers, multiple answers were accepted, and results obtained are summarized in Figure 4.

Respondents who highlighted other situations mentioned a wide range of situations, such as non-formal education, activities within the methodical commission, volunteer actions, first degree paper, national geography competitions, extracurricular projects ("Eco-school, Eco-education for green schools"), field trips/visits in the local area, school geography magazine, geography debates, conferences and symposia for students and teachers.

A wide range of curricula were also presented at the decision of the school where the analyzed notions were introduced; most subsumed environmental issues and its conservation, tourism or geography of the local space ("Ecology and environmental protection, Natural and anthropogenic 
disasters, Natural and anthropogenic hazards, Let's live in an ecological environment, Create your environment, Green ideas for the blue planet, Earth and its geospheres, Let's learn to love nature, Superlatives of the Earth, World curiosities, Enigmas on Earth, Picturesque Romania, Geography of the native county, Geography tourism, Romania's relief-unity in diversity, Romania's tourism potential, Europe-geographical regions, Sustainable development in tourism, Tourism heritage, Tourism in the world, Tourism in the Carpathians, Tourism in Europe, Travel through Romania counties").

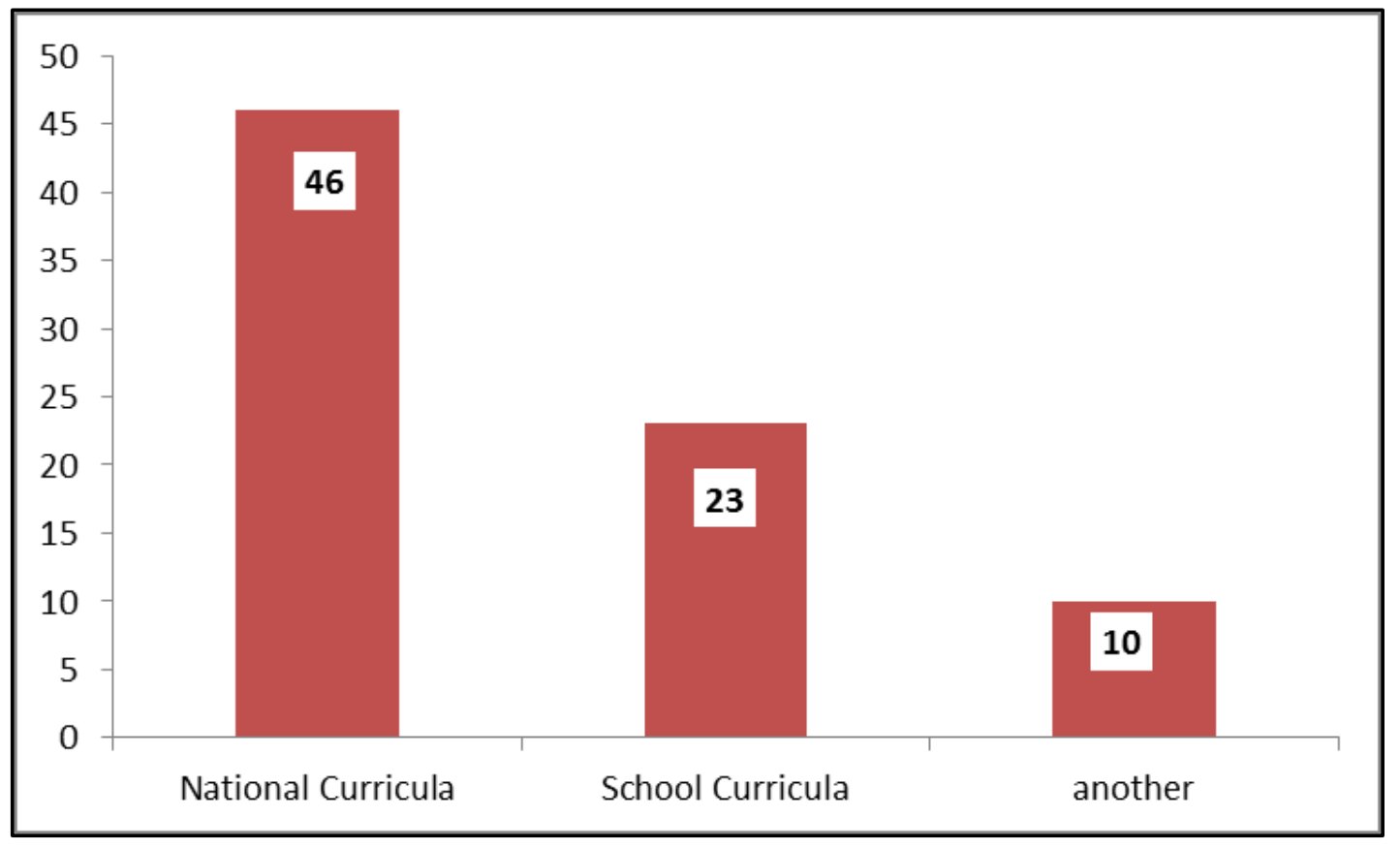

Figure 4. The educational context in which teachers used the geoheritage and geodiversity concepts.

At a rate of $98.61 \%$, the teaching staff (with one exception, the respondent teaching Mathematics) consider it necessary to introduce such notions in the national curriculum (learning units such as Biogeography; Relief; Local Geography; Environmental Protection; Environment, Landscape and Human Society) as well as in the school decision curriculum (grades V, VI, VIII, IX, XI, XII). Although the sample was mainly composed of geography teachers, in 14 cases (19.44\%), they mentioned other disciplines such as biology, history, philosophy, civic culture, tourism and environmental protection (in vocational classes at technology high schools) where these notions can be introduced, proving that teachers understand and become aware of the inter- and transdisciplinary nature of these concepts ("starting with young people in subjects such as environmental knowledge, geography, biology, even in Romania, dedicated papers can be found with and information about the environment, texts that students can use to later analyze aspects related to vocabulary and grammar, as well as when studying foreign languages"). Teachers also appreciate the importance of knowing these notions as an educational/scientific foundation and compulsory competence, but they also appreciate the fact that for the 12th grade, it is useful that there is "a better understanding of them in order to motivate more students to choose to study at a University and in order for them to be involved in projects for conservation, protection and promotion of natural heritage. There is also a deeper awareness of the aspects related to protection, conservation, laws, projects, involvement of today's students ... tomorrow's people".

When asked about the educational projects carried out with the students, $53.93 \%$ of the interviewed teachers carried out different types of projects, while $46.07 \%$ did not get involved in such activities. Among the exemplified projects, we drew attention to trips, especially in the local horizon (Local space - past and present); projects related to the environment ("Reservations in a certain area, monuments of nature; Nature-laboratory for research, education, innovation; Children's environmental guard; Nature-friendly 
schools; Children in support of nature; Forest moon; Earth—our home; ECO School; Tree school; Let's learn about nature; Blue Danube river project-Save water; Don't destroy what you did not create") and tourism (at the level of Romania, "With my virtual backpack, on the mountain paths"); the celebration of certain days ("Biodiversity, Environment, Earth, GIS Day"); competitions on various environmental topics, geology and speleology, heritage projects ("Protecting heritage-innovative ideas, Heritage promotion techniques in the context of sustainable development").

Regarding the interviewees' grading on a scale from 1 to 10 of the importance of the concepts of geoheritage and geodiversity, it was found that the respondents of both categories were aware of their value, with the average of the grades obtained being 9.45 for teachers and 9.58 for students. For both samples, we noted that there were no grades lower than 7 .

One hundred percent of students considered these notions important, especially in terms of geoheritage conservation. Thus, from the question addressed to the students related to the measures to be taken for its conservation (multiple answers were allowed), six directions of action were established (Table 5, Figure 5). Of these, the largest share of responses was for the direction of education $(92.00 \%)$, and the lowest was for promotion (19.00\%). This demonstrates that students are convinced that knowledge, protection and conservation of geoheritage is promoted primarily through education.

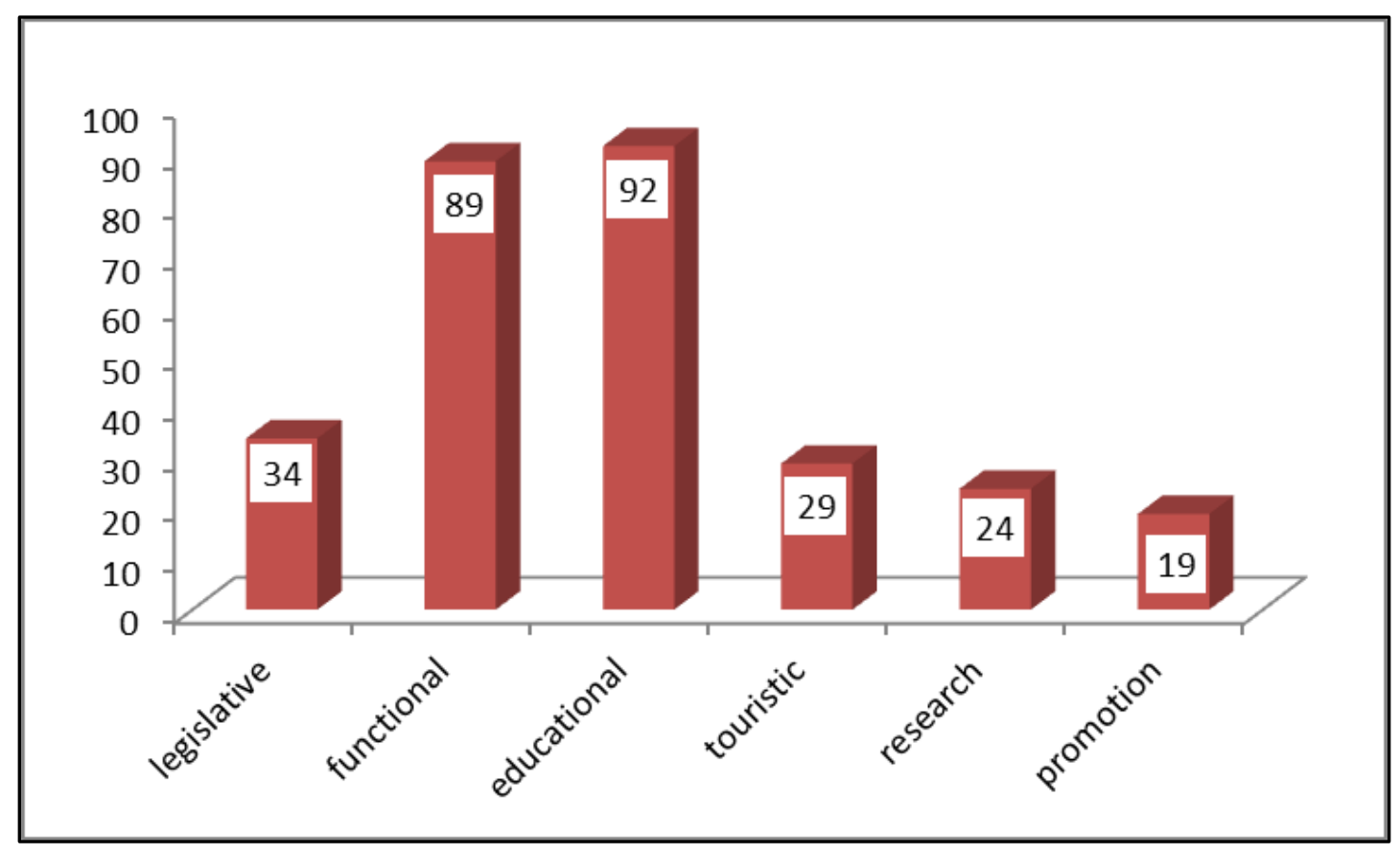

Figure 5. The weight of student responses (\%) for each type of measures proposed for geoheritage conservation. 
Table 5. The types of measures proposed for geoheritage conservation (according to the students).

\begin{tabular}{|c|c|}
\hline Direction & Measures \\
\hline Legislative & 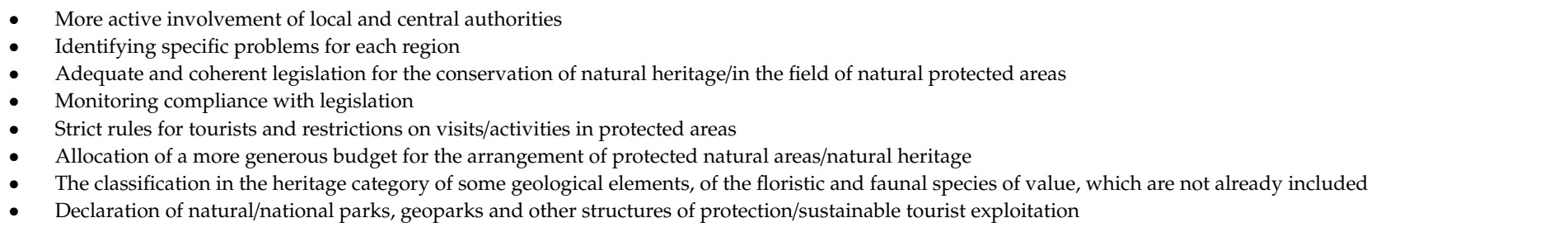 \\
\hline Functional & $\begin{array}{l}\text { - Stopping illegal deforestation } \\
\text { - } \\
\text { - } \\
\text { - } \\
\text { - } \\
\text { - }\end{array}$ \\
\hline Educational & $\begin{array}{l}\text { - Early thematic education at the gymnasium level and its continuation in high school } \\
\text { - Introducing into the curriculum some disciplines/contents aimed at the protection of the natural heritage } \\
\text { - } \quad \text { Educating the population through materials and seminars given by students in regions where there are elements of heritage (explanation of basic concepts) } \\
\text { - Creating volunteer programs } \\
\text { - } \quad \text { Esclusion in the school program of some applicative activities in natural parks/geomorphological reservations in which the students can study the conserved elements } \\
\text { - Organizing thematic excursions with childrens and field trips with geography students in areas with heritage elements }\end{array}$ \\
\hline Tourist & $\begin{array}{l}\text { - Carrying out guided tours and information panels in areas with natural heritage elements } \\
\text { - } \quad \text { Pimiting tourist access (maximum number per day), higher taxes (to discourage mass tourism), more efficient administration of sites } \\
\text { - Recognition of the potential of each site for conservation and tourism development }\end{array}$ \\
\hline Research & $\begin{array}{l}\text { - Increasing budgets for research funding in the field } \\
\text { - Carrying out advanced research to show the importance of heritage and its protection measures } \\
\text { - Inventory and mapping of high-value areas of geological and geomorphological heritage } \\
\text { - } \quad \text { Determining and presenting the importance of geodiversity as a support for biodiversity }\end{array}$ \\
\hline Promotion & $\begin{array}{l}\text { - Promotion of natural heritage } \\
\text { - Promoting protection measures in the media } \\
\text { Promoting the areas where there are heritage objectives for attracting funds }\end{array}$ \\
\hline
\end{tabular}




\section{Conclusions}

Geoeducation must be carried out both in and out of school; it involves the formation of not only attitudes and skills, but also the knowledge of concepts that people will need in life. The main objectives of geoeducation and the study of geoheritage, on a larger scale, are: understanding how social, physical and living systems work and interact; knowledge of various cultures, ecosystems and natural physical systems; the ability to communicate across cultural and geographical boundaries; analysis of various situations (especially in nature) using the tools and perspectives of different sciences [36]. In Romania, the results obtained from the application of the questionnaire show us significant differences between the educational cycles: for pre-university education, it takes place either formally (in the curriculum at the school's decision) or non-formally (trips, projects), and in university education, it is formal (courses or content dedicated to most universities in the country, or in field applications included in the curriculum). When it is non-formal, it is organized by student associations/NGOs.

There is a need for some positive elements of the German experience [37] to be applied in Romania by supporting teachers, especially those in middle and high school education, to achieve interdisciplinary geoeducation, both in and out of the classroom, to use educational platforms and practical materials/samples from museums, especially science museums, and to benefit from the experience of researchers.

In the United States [36], the results are not so gratifying: especially in recent decades, the teaching of geosciences has suffered greatly compared to that of traditional sciences (biology, physics, chemistry), and allotted time to geography and social sciences has been decreasing significantly in the national curriculum. Moreover, the main way in which geoeducation is performed in school is through the use of geographical information systems.

In Switzerland [38], geoeducation is closely related to the application of geographical information systems in schools and to the processing of such information by students.

In France, geoeducation is carried out in an interdisciplinary manner (involving geography, history and social sciences), being a model in this regard. Outdoor activities are encouraged, involving children's free discovery of the elements of the natural environment.

Proof that geoeducation is of great importance for the future was shown in Africa, with the African Network for Geo-education. "The African Network for Geo-Education exists to develop a [way for] professional geoscientists and educators to provide geoscience outreach to all" [39].

The limitations of the present study may arise from the rather limited number of questionnaires that were applied, from the limited geographical distribution of respondents and from the terminological confusions discovered. Furthermore, the special period in which questionnaires were given (in the middle of the COVID 19 pandemic) greatly limited the spectrum of formal and non-formal activities carried out as well as the availability of pre-university teachers to respond to our requests.

In the future, we intend to apply similar questionnaires focused on the target group of teachers in university education who teach or research these notions and to correlate them with the opinions of the beneficiaries of education, namely students. A stronger connection is also required between the university space where these concepts have penetrated strongly and correctly and the pre-university space, which, despite remarkable efforts, is still limited to environmental education and where the trans-/interdisciplinary character remains a theoretical goal.

We intend to disseminate the results of this study among decision-makers and determine the most appropriate ways for there to be a greater presence of these concepts both formally and informally in the Romanian education system.

Author Contributions: All authors have contributed equally in the development of this article. All authors have read and agreed to the published version of the manuscript.

Funding: This research received no external funding.

Conflicts of Interest: The authors declare no conflict of interest. 


\section{References}

1. Pereira, P.; Pereira, D.; Alves, C.; Brilha, J. Geology, landscape and geomorphology: Finding the place of geomorphological heritage. In Proceedings of the IV International Symposium PROGEO, Braga, Portugal, 13-16 September 2005.

2. Reynard, E.; Giusti, C. The landscape and the cultural value of Geoheritage. In Geoheritage: Assessment, Protection, and Management; Reynard, E., Brilha, J., Eds.; Elsevier: Amsterdam, The Netherlands, 2018; pp. 147-167.

3. Stanley, M. Geodiversity-Linking people, landscapes and their culture. In Natural and Cultural Landscapes-The Geological Foundation; Parkes, M., Ed.; Royal Irish Academy: Dublin, Ireland, 2004; pp. 45-52.

4. Panizza, M.; Piacente, S. Cultural geomorphology and geodiversity. In Geomorphosites; Reynard, E., Coratza, P., Regolini-Bissig, G., Eds.; Pfeil: Munich, Germany, 2009; pp. 35-48.

5. Coratza, P.; Gauci, R.; Schembri, J.; Soldati, M.; Tonelli, C. Bridging natural and cultural values of sites with outstanding scenery: Evidence from Gozo, Maltese Islands. Geoheritage 2016, 8, 91-103. [CrossRef]

6. Carreras, J.; Druguet, E. Geological heritage, an essential part of the integral management of world heritage in protected sites. In Geological Heritage and Its Conservation and Management, Proceedings of the Third International Symposium Pro Geo on the Conservation of the Geological Heritage, Madrid, Spain, 23-25 November 1999; Barretino, D., Wimbledon, W.A.P., Gallego, E., Eds.; Geological and Mining Institute: Madrid, Spain, 2000; pp. 95-110.

7. Gray, J.M. Other nature: Geodiversity and geosystem services. Environ. Conserv. 2011, 38, 271-274. [CrossRef]

8. Gordon, J. Rediscovering a sense of wonder: Geoheritage, geotourism and cultural landscape experiences. Geoheritage 2012, 4, 65-77. [CrossRef]

9. Guichard-Anguis, S.; Heritier, S. Le patrimoine naturel entre culture et resource. Geogr. Cult. 2008, 66, 138.

10. Migon, P. Geomorphological Landscapes of The World; Springer: Dordrecht, The Netherlands, 2010.

11. Lowenthal, D. Natural and cultural heritage. Int. J. Herit. Stud. 2005, 11, 81-92. [CrossRef]

12. Migon, P. Geoheritage and World Heritage sites. In Geoheritage: Assessment, Protection, and Management; Reynard, E., Brilha, J., Eds.; Elsevier: Amsterdam, The Netherlands, 2018; pp. 237-250.

13. Pralong, J.P. A method for assessing the tourist potential and use of geomorphological sites. Géomorphologie 2005, 3, 189-196. [CrossRef]

14. Coratza, P.; Giusti, C. Methodological proposal for the assessment of scientific quality of geomorphosites. J. Quat. Sci. 2005, 18, 307-313.

15. Reynard, E.; Fontana, G.; Kozlik, L.; Scapozza, C. A method for assessing "scientific" and "additional values" of geomorphosites. Geogr. Helv. 2007, 62, 148-158. [CrossRef]

16. Comănescu, L.; Ielenicz, M.; Nedelea, A. Relieful şi Valorificarea lui în Turism; Ars Docendi: Bucharest, Romania, 2010.

17. Brilha, J. Inventory and quantitative assessment of geosites and geodiversity sites: A review. Geoheritage 2016, 8, 119-134. [CrossRef]

18. Sellier, D. A deductive method for the selection of geomorphosites: Application to Mont Ventoux (Provence, France). Geoheritage 2016, 8, 15-29. [CrossRef]

19. Bruschi, V.M.; Coratza, P. Geoheritage and environmental impact assessment (EIA). In Geoheritage: Assessment, Protection, and Management; Reynard, E., Brilha, J., Eds.; Elsevier: Amsterdam, The Netherlands, 2018; pp. 251-262.

20. Ovreiu, A.B.; Comănescu, L.; Bărsoianu, I.A.; Nedelea, A. Evaluating geomorphosites and the geomorphological hazards that impact them: Case study-Cozia Massif (Southern Carpathians. Romania). Geoheritage 2019, 11, 1067-1087. [CrossRef]

21. Gray, M. Geodiversity and geoconservation: What, why and how? In Geodiversity E Geoconservation; Santucci, V.L., Ed.; George Wright Forum: Hancock, MI, USA, 2005; Volume 22, p. 3.

22. Gray, M. Geodiversity_Valuing and Conserving Abiotic Nature, 2nd ed.; Willey Blackwell: Chichester, UK, 2013.

23. Stanley, M. Editorial. Geodiversity Update 2001, 1, 1.

24. Geremia, F.; Bentivenga, M.; Palladino, G. Environmental geology applied to geoconservation in the interaction between geosites and linear infrastructures in South-Eastern Italy. Geoheritage 2015, 7, $33-46$.

25. Panizza, M. The geomorphodiversity of the Dolomites (Italy): A key of geoheritage assessment. Geoheritage 2009, 1, 33-42. [CrossRef] 
26. Comănescu, L.; Nedelea, A. Analysis of some representative geomorphosites in the Bucegi Mountains: Between scientific evaluation and tourist perception. Area 2010, 4, 406-416. [CrossRef]

27. Gray, M. Geodiversity: Valuing and Conserving Abiotic Nature; John Wiley \& Sons Ltd.: Chichester, UK, $2004 ;$ p. 434.

28. Serrano, C.; Ruiz-Flano, P. Geodiversity: Concept, assessment and territorial aplication. The case of Tiermes -Caracena (Soria). Boletín Asoc. Geógrafos Españoles 2007, 45, 389-393.

29. Zwoliński, Z.; Najwer, A.; Giardino, M. Methods for assessing geodiversity. In Geoheritage: Assessment, Protection, and Management; Reynard, E., Brilha, J., Eds.; Elsevier: Amsterdam, The Netherlands, 2018; pp. 27-52.

30. Andrășanu, A. Geoconservarea-Concepte, Metodologie, Aplicații-Geoconservarea FormațIunilor de Vârstă Cretatic Inferior Din Bazinul Dâmbovicioara. Ph.D. Thesis, University of Bucharest, Bucharest, Romania, 2008.

31. Brilha, J. Geoheritage: Inventories and evaluation. In Geoheritage: Assessment, Protection, and Management; Reynard, E., Brilha, J., Eds.; Elsevier: Amsterdam, The Netherlands, 2018; pp. 69-82.

32. Berrebi, Y. Les Sentiers Didactiques: Analyse de la Perception du Public Face à Quatre Réalisations Géodidactiques, Mémoire de Licence; UNIL, Institut de Géographie: Lausanne, Switzerland, 2006.

33. Sellier, D. La vulgarisation du patrimoine géomorphologique: Objets, moyens et perspectives. Géographies Bull. Assoc. Géographes Français 2009, 86, 67-81. [CrossRef]

34. Cayla, N.; Hobléa, F.; Gasquet, D. Guide des bonnes pratiques de médiation des géosciences sur le terrain. Géologie Fr. 2010, 1, 47-55.

35. Bollati, I.; Pelfni, M.; Pellegrini, L.; Bazzi, A.; Duci, G. Active geomorphosite and educational application: A didactical itinerary along Trebbia River (Northern Apennines, Italy). In Les Géosciences au Service de la Société; Reynard, E., Laigre, L., Kramar, N., Eds.; Institut de géographie, Université de Lausanne: Lausanne, Switzerland, 2011; Volume 37, pp. 219-234.

36. Available online: https://www.nationalgeographic.org/education/geo-education-essential-preparationinterconnected-world/ (accessed on 1 September 2020).

37. Bergner, A.; Bookhagen, B.; Ellger, C.; Schneider, S. GeoEd: Teaching teachers for a better GeoEducation in Germany. In Proceedings of the Conference: European Geosciences Union General Assembly, Vienna, Austria, 12-17 April 2015.

38. Swiss Centre for Geomatics Education-Technically Committed to Shaping the Environment. Available online: https://geo-education.ch/?lang=en (accessed on 22 October 2020).

39. African Network for Geo-Education. Available online: https://sites.google.com/site/geoeducationafrica/ (accessed on 22 October 2020).

Publisher's Note: MDPI stays neutral with regard to jurisdictional claims in published maps and institutional affiliations.

(C) 2020 by the authors. Licensee MDPI, Basel, Switzerland. This article is an open access article distributed under the terms and conditions of the Creative Commons Attribution (CC BY) license (http://creativecommons.org/licenses/by/4.0/). 